https://doi.org/10.48009/2_iis_2007_83-88

\title{
CORPORATE CYBERSPACE COMMUNICATION VS. PAPER-BASED COMMUNICATION: THE IMPACT OF MEDIA CHOICE ON COST AND BENEFIT
}

\author{
Dr. Jensen J. Zhao, Ball State University, jzhao@bsu.edu \\ Dr. Joel A. Whitesel, Ball State University, jawhitesel@bsu.edu \\ Dr. Allen D. Truell, Ball State University, atruell@bsu.edu \\ Dr. Melody W. Alexander, Ball State University, malexand@bsu.edu
}

\begin{abstract}
This study investigated how corporate media choices such as cyberspace and paper-based communication impacted cost and benefit. Data were collected from the Fortune 500 companies. The findings indicated that, while all the companies provided the Web version of annual reports on their investor relations page, 53\% of the companies still printed and distributed paper-based annual reports in 2005. The average cost of designing, printing, and distributing paper-based annual report was more than \$1.7 million per company in one year, which also consumed approximately 647,059 pounds of paper. In contrast, the costs of $C D$ - and Web-based annual reports were only $21 \%$ and $3 \%$ of the cost of the paper version, respectively. In addition, the cost of distributing e-coupons by email was just $2 \%$ of the cost of mailing paper coupons via postal service.
\end{abstract}

Keywords: Cyberspace communication, paper-based communication, annual report, email, $\mathrm{CD}$, cost and benefit

\section{INTRODUCTION}

The Internet and Web technologies have enabled people to communicate in cyberspace far more efficiently than on paper in terms of speed, interactivity, flexibility, and cost, to name a few. However, changing from paper-based communication to paperless cyberspace communication remains a challenge (6). Every year companies spend tons of paper to print annual reports, quarterly financial statements, and sales promotions and then mail them to their shareholders, investors, and customers, respectively. Such a large-scale communication incurs a substantial annual cost to each company. Given the common goal for publicly traded businesses to maximize shareholders' value (13), companies need to consider other more cost-effective media for publishing and distributing their annual reports and other investor and customer communications.
As the surveys of the National Investor Relations Institute $(10,11)$ reported, although $95 \%$ of its 5,000 member companies posted annual reports online, $88 \%$ of the companies still produced paper-based annual reports, of which $32 \%$ printed the traditional annual reports and $56 \%$ printed the shorter, more financially focused $10-\mathrm{K}$ wraps. A $10-\mathrm{K}$ wrap is a new type of annual report printed in black and white on low cost, no frilly paper with all the information required by Sarbanes-Oxley Act (5). The average cost per printed paper copy was $\$ 3.91$ with an average of 73 pages (10).

Some information technologists, business executives, and environmental protectionists criticized that publishing an 80-page or even a 50-page report and distributing it to tens of thousands of people is a tremendously wasteful exercise, because in many cases only a small portion of those who have received a report actually use it and many costly reports are simply thrown out; every year an average of 700 pounds of paper products ( $\approx$ one ton of hardwood) is used per person in America (e.g., 1, 7, 8). Active investors today want information quickly, they want it up-to-date, they want it continuously, and they get it instantly on the Web (1). To avoid such a huge waste of natural and financial resources, Blunn (1) suggested that companies need to persuade their shareholders to agree to accept annual reports and quarterly statements electronically.

To help companies identify persuasive ways to get shareholders and customers to accept annual reports and other communications electronically, this study attempted to investigate the financial impact of corporate media choice. The investigation focused on (a) the current status of corporate media choice for creating and distributing annual reports and other investor and customer communications among the Fortune 500 companies, and (b) the impact of different media choice on cost and benefit. The Fortune 500 companies were used because they are publicly traded companies representing a wide range 
of industries. The findings of the study would provide business executives, investors, customers, IT educators and students, and environmental protectionists with useful information that they need to help reduce corporate communication cost, maximizing shareholders' value, sharing savings with customers, and consuming fewer trees and other scarce natural resources.

\section{METHODS}

As the literature documented that the survey response rate of the Fortune 500 and Fortune 1,000 corporations ranged just between $10 \%$ and $19 \%$ (e.g., $3,4,12)$, we contacted all the companies on the Fortune 500 list (9) to assure a representative number of companies willing to participate in this study. We requested each company to mail us printed annual reports and to provide any information available regarding the cost and benefit of producing and distributing paper-based annual reports vs. Webbased ones.

After receiving the paper-based annual reports, we recorded the following information: postage cost, dimensions of report, binding, number of pages, and use of color. The Web-based annual reports were compared with the printed versions to determine the similarities and differences in layout design, text, graphics, color, as well as their costs and benefits.

Compact disk (CD) was also examined as an alternate medium for distributing digital annual reports. The cost for this method was established by getting the prices of CDs and mailing jackets, and then taking a $\mathrm{CD}$ and a mailing jacket to the Post Office for the postage cost. To estimate the cost of creating CDs, an online search was conducted for production facilities geared toward to mass production of CDs.

Other paper-based business communication such as quarterly financial statements and sales promotions and their online versions were collected from the Fortune 500 companies in investment, retailing, direct sale, and wholesale businesses, such as Charles Schwab, E*Trade Financial, Sears, Dell, HP, and Costco Wholesale. Data were analyzed comparatively to determine the cost and benefit of different choice of media.

\section{FINDINGS}

Two hundred sixty-three printed annual reports were received by postal mail, which represented $53 \%$ of the Fortune 500 companies. Among them, 228 had postmarks showing postage cost. The average postage cost per annual report was $\$ 2.79$, with the maximum of $\$ 7.85$ and the minimum of $\$ 1.06$ each. Of the 228 annual reports, $58 \%$ were printed in color and $42 \%$ in black and white, $76 \%$ were bound with glue and $24 \%$ with staple, the average length was 90 pages, and sized at or around $81 / 2 \times 11$ inches.

Regarding the cost of designing and producing paperbased annual reports, only 11 companies provided information and all of them asked not to be identified. As Table 1 shows, the average print run of the 11 companies for their 2005 annual reports was near half million $(431,373)$ copies, with a cost of more than half million dollars $(\$ 525,200)$ in design and print, not including postage.

\section{[Insert Table 1 about here]}

All the Fortune 500 companies provided online versions of annual reports or 10-K wraps and other corporate information on their investor relations page. When asked about the cost of designing and developing their Web-based annual reports, respondents reported that since their annual reports were designed and developed digitally, they just spent an annual budget of $\$ 20,000$ to $\$ 30,000$ in converting the report files into PDF, HTML, or TXT format, and then posting them on the investor relations page. Since the companies already had Web sites, the incremental cost of hosting the annualreport files was minimal and not part of the budget.

The cost of copying annual reports on $\mathrm{CD}$ with a screen print on it was less than $\$ 0.50$ each for lots of 1,000 , and could drop as low as $\$ 0.18$ in quantities of half a million. The cardboard sleeves used for mailing CDs cost less than $\$ 0.05$ each. According to the responses from three companies, the total cost for mass producing and shipping CD-based annual reports was approximately $\$ 0.75$ each, not including the cost of developing the content.

Table 2 illustrates comparisons of the cost and benefit of designing, producing, and distributing annual reports in three different media (paper, CD, and $\mathrm{Web}$ ) based on the averages of the 11 Fortune 500 companies. As shown in Table 2, the grand total cost of the paper-based annual reports per company was more than $\$ 1.7$ million a year, meaning that the paper-based report was most expensive among the three media. If a company mailed the CD-based annual report, rather than the paper version, to its shareholders and investors, the company could benefit from a saving of $79 \%$ or more than $\$ 1.3$ million. If a company turned completely to the Web- 
based version, it could benefit from a huge saving of $97 \%$ or more than $\$ 1.6$ million per year.

\section{[Insert Table 2 about here]}

Companies in investment, retailing, direct sale, and wholesale businesses such as Charles Schwab, E*Trade Financial, Sears, Dell, HP, and Costco Wholesale periodically mail paper-based quarterly statements and sales promotions to investors and customers, respectively. The postal bulk rate for such mails ranged from $\$ 0.29^{\frac{3}{2}}$ to $\$ 0.53$ to $\$ 0.96^{\frac{1}{1}}$ each, with the majority cost $\$ 0.53$ each. By contrast, offering the email version of such communications would save companies a lot of money each year. For example, at the time of the study, Costco Wholesale had a total membership of near 48 million people (2), and the company used postal service to mail coupon books to its members approximately four times a year for promoting manufactures' sponsored sales. As Table 3 shows, the postal mailing cost was $\$ 0.53$ in bulk rate per each book of 10 pages, and the total annual cost of mailing coupon books to 48 million members was $\$ 101.76$ million just for the postal service. If Costco used email to send e-coupon books to its members, the total annual cost would just be $\$ 1.92$ million, which generated a saving of $98 \%$ or $\$ 99.84$ million each year.

\section{[Insert Table 3 about here]}

\section{CONCLUSIONS AND RECOMMENDATIONS}

While all the Fortune 500 companies had Web versions of annual reports and other business communication in PDF, HTML, or TXT format on their investor relations page, $53 \%$ of the companies printed and distributed paper-based annual reports in 2005 . The average print run per company was 431,373 copies and average length per copy was 90 pages, which cost a company more than $\$ 1.7$ million in design, print, and postage. This also means a consumption of approximately 647,059 pounds of paper or 863 tons of hardwood according to the paper industry's calculation (8).

In contrast, the same 431,373 copies of CD-based annual reports would just cost $\$ 0.36$ million in production and postage, meaning that a company could save $79 \%$ of that $\$ 1.7$ million. At the same time, its shareholders could still receive a tangible copy of the company annual report in their postal mail box.

Furthermore, providing Web versions of annual reports on companies' investor relations page was most cost-effective. The average total cost for a Fortune 500 company in 2005 was $\$ 57,400$, which included the design cost of $\$ 35,400$ and production cost of $\$ 22,000$. If a company would be able to just provide annual reports on the Web, the company and its shareholders could benefit from a huge saving of $97 \%$ or more than $\$ 1.6$ million as compared with the cost of paper-based annual report. Certainly, the Web does not eliminate entirely the cost of printing financial reports but transfers part of the cost to individuals, who prefer to print hard copies from the Web.

In addition, companies could cut the cost of producing and distributing paper-based quarterly statements and sales promotions if they could send such information via email. The average postal cost per each mail of 6-10 pages was $\$ 0.53$ in bulk rate. In contrast, the cost of sending the same information via email would cost $\$ 0.01$ each at most, which means an enormous saving of $98 \%$. If companies in investment, retailing, direct sale, and wholesale businesses would send quarterly statements and coupon books via email to their shareholders and customers, respectively, the companies could save millions of dollars each year.

To persuade shareholders and customers to agree to accept the electronic versions of annual reports, quarterly statements, and sales coupons, we recommend that companies should consider the following alternatives:

First, companies can communicate with their shareholders on (a) how important it is to consume less paper and save more trees and water, (b) how companies could maximize shareholders' value if shareholders agree to accept Web-based annual reports instead of the paper version, and (c) how the financial statements of Web-based reports could be easily imported into a spreadsheet on readers' computers for additional customized analysis and comparison.

Second, if more than half of the shareholders of a company insist in receiving a tangible copy of annual report, the company could mail them a CD version of the report and continue to persuade them to accept the online version as being an environment-friendly citizen and cost-sensitive shareholder.

Third, companies could also follow the airline industry's example of changing from traditional paper tickets to e-tickets. Between 1995 and 2001, most airlines companies encouraged customers to buy tickets at their Web sites by rewarding purchase 
of each round-trip e-ticket with 1,000 mile points added to their frequent flier accounts such as United Mileage Plus, NWA WorldPerks, and American Airlines AAdvantage program. Since 2002, when customers telephone the airlines to buy e-tickets, the automated phone systems first inform the callers that a call-center fee from $\$ 10$ (e.g., USAir) to $\$ 15$ (e.g., United Airlines) will be added to each ticket if they prefer to purchase it by phone. In addition, when customers request a traditional paper ticket, the airlines will charge a paper-ticket fee from $\$ 20$ (e.g., United Airlines) to $\$ 50$ (e.g., USAir) per ticket.

We also recommend that academic and professional associations should consider publishing CD- and Web-based journals instead of the traditional paper version to reduce the costs of paper, print, and distribution, as well as to save more natural resources.

\section{REFERENCES}

1. Blunn, C. (2001, September 28). Whither the annual report. Retrieved October 31, 2006 from http://www.blunnco.com/about/perspectives/pers pective0901.html

2. Boyle, M. (2006, October). Why Costco is so damn addictive. Fortune, 154(9), 126-132.

3. Heidrick \& Struggles. (2002). CFOs: Strategic business partners. Retrieved January 16, 2002, from http://www.heidrick.com/public/services/industr ydata.html

4. Jones, S. (1999). 1999 Fortune 500 security systems benchmark report. Retrieved January 16, 2002, from http://www.sandrajonesandco.com/fort500con.ht $\underline{\mathrm{m}}$
5. Saltzman, E. (2006). It's a wrap...or is it? Retrieved February 26, 2006 from http://www.addison.com/perspectivedetails.aspx?PerspectiveID $=15 \&$ PracticeName $=$ Annual\%20Reports

6. Sellen, A. J. \& Harper, H. R. (2001). The Myth of the Paperless Office. Cambridge, MA: MIT Press.

7. Sellers, P. (2006, November). The Net's next phase. Fortune, 154(10), 71-74.

8. TAPPI, (2006). How much paper do Americans use in a year? Paper University. Retrieved November 1, 2006 from http://www.tappi.org/paperu/all_about_paper/faq .htm

9. The Fortune 500 largest U.S. corporations. (2005, April). Fortune, 151(8), F1-20.

10. Thompson, L. M. (2004). NIRI releases annual report survey. The National Investor Relations Institute Executive Alert, 9,1-4.

11. Thompson, L. M. (2006). NIRI releases annual report survey. The National Investor Relations Institute Executive Alert. Retrieved November 1, 2006 from http://www.niri.org/irresource pubs/alerts/notme m.cfm?id $=58$

12. Urresta, L. \& Hickman, J. (1998, August). The diversity elite. Fortune, 138(3), 114-122.

13. Value Based Management (2006). Shareholder Value Perspective versus the Stakeholder Value Perspective. Retrieved February 3, 2006 from http://www.valuebasedmanagement.net/faq shar eholder_stakeholder_perspective.html 
Table 1

Design and Print Cost of Paper-Based Annual Reports of Fortune 500 Corporations

\begin{tabular}{rrrr}
\hline Company & Print Run & $\begin{array}{c}\text { Total Design and } \\
\text { Print Cost }\end{array}$ & $\begin{array}{c}\text { Design and Print Cost } \\
\text { per Copy }\end{array}$ \\
\hline 1 & $3,000,000$ & $\$ 1,800,000.00$ & $\$ 0.60$ \\
2 & 565,000 & $\$ 497,000.00$ & $\$ 0.88$ \\
3 & 300,000 & $\$ 1,129,000.00$ & $\$ 3.76$ \\
4 & 219,400 & $\$ 601,200.00$ & $\$ 2.74$ \\
5 & 150,000 & $\$ 275,000.00$ & $\$ 1.83$ \\
6 & 148,000 & $\$ 390,000.00$ & $\$ 2.64$ \\
7 & 90,000 & $\$ 350,000.00$ & $\$ 3.89$ \\
8 & 90,000 & $\$ 180,000.00$ & $\$ 2.00$ \\
9 & 65,700 & $\$ 220,000.00$ & $\$ 3.35$ \\
10 & 61,000 & $\$ 120,000.00$ & $\$ 1.97$ \\
11 & 56,000 & $\$ 215,000.00$ & $\$ 3.84$ \\
\hline Average & 431,373 & $\$ 525,200.00$ & $\$ 1.22$ \\
\hline
\end{tabular}

Table 2

Average Cost and Benefit Comparison of Paper-, CD-, and Web-based Annual Reports Among 11 Fortune 500 Corporations

\begin{tabular}{|c|c|c|c|c|c|}
\hline \multirow[b]{2}{*}{ Category } & \multicolumn{5}{|c|}{ Annual Reports } \\
\hline & Paper-Based & Vs. & CD-Based & vs. & Web-Based \\
\hline Design Cost & $\$ 35,400.00$ & & $\$ 35,400.00$ & & $\$ 35,400.00$ \\
\hline Print Run & 431,373 & & 431,373 & & 0 \\
\hline Print Cost per Copy & $\$ 1.14$ & & $\$ 0.36$ & & $\$ 0.00$ \\
\hline Print Cost & $\$ 489,800.32$ & & $\$ 155,294.28$ & & $\$ 22,000.00$ \\
\hline Total Design-Print Cost & $\$ 525,200.32$ & & $\$ 190,694.28$ & & $\$ 0.00$ \\
\hline Postage per Copy & $\$ 2.74$ & & $\$ 0.39$ & & $\$ 0.00$ \\
\hline Total Postage & $\$ 1,181,962.02$ & & $\$ 168,235.47$ & & $\$ 0.00$ \\
\hline Grand Total Cost & $\$ 1,707,162.34$ & & $\$ 358,929.75$ & & $\$ 57,400.00$ \\
\hline $\begin{array}{c}\text { Saving by using } \mathrm{CD} \text { and } \mathrm{Web} \\
\text { against Paper }\end{array}$ & & & $\$ 1,348,232.59$ & & $\$ 1,649,762.34$ \\
\hline Saving in $\%$ & & & $79 \%$ & & $97 \%$ \\
\hline
\end{tabular}


Table 3

Cost and Benefit Comparison Between Postal Mail and Email to Customers of Costco Wholesale Corporation

\begin{tabular}{|c|c|c|c|c|}
\hline \multirow[b]{2}{*}{ Category } & \multicolumn{3}{|c|}{ Coupon Distribution } & \multirow[b]{2}{*}{ Saving } \\
\hline & Postal Mail & vs. & Email & \\
\hline \# of Membership & $48,000,000$ & & $48,000,000$ & \\
\hline Mailing Frequency per Year & 4 & & 4 & \\
\hline Mailing Cost per Coupon Book & $\$ 0.53$ & & $\$ 0.01$ & $\$ 0.52$ \\
\hline $\begin{array}{l}\text { Total Annual Cost } \\
\text { Saving in } \%\end{array}$ & $\$ 101,760,000.00$ & & $\$ 1,920,000.00$ & $\begin{array}{r}\$ 99,840,000.00 \\
98 \%\end{array}$ \\
\hline
\end{tabular}

